\title{
Mewujudkan Guru SD Yang Ideal
}

\author{
IMROATUS SOLIKAH \\ Universitas Nahdlatul Ulama Sidoarjo \\ Email : imroatussolikah482@gmail.com
}

\section{Pengantar}

Secara etimologis, guru berasal dari bahasa India artinya orang yang mendidik kelepasan dan sengsara. Rabinranath Tagore (1986-1941), Istilah shanti Niketan atau rumah damai untuk tempat para pendidik mengamalkan tugas mulia dalam mengembangkan spiritualitas anak-anak India (spiritual intelligence). Dalam bahasa arab, guru disebut dengan al-mua'allim atau al-ustadz yang bertugas memberi ilmu dalam majelis taklim (tempat memperoleh ilmu). Dengan ini, al-mua'allim atau alustadz, ini juga mempunyai pengertian orang yang mempunyai tugas untuk aspek mengembangkan spiritualitas manusia.

\section{Pengertian Guru}

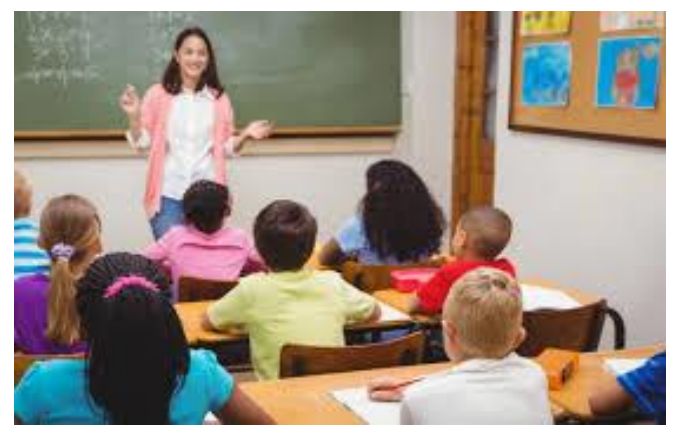

Gambar : www.gambarmania

Guru merupakan pendidik, seorang manusia dewasa yang memikul tanggung jawab untuk memberikan informasi atau bantuan ke siswa dalam mewujudkan tubuh dan jiwa untuk mencapai kematangan, mampu berdiri sendiri dan dapat melaksanakan tugasnya sebagai khalifah allah di bumi, sebagai makhluk sosial dan individu yang mampu berdiri sendiri (Noor Jamaluddin 2018). 
Guru merupakan pendidikan yang profesional karena guru menerima dan memikul tanggung jawab dari orang tua untuk mendidik anak-anaknya. Dalam hal ini orang tua juga sebagai pendidik yang pertama dan utama bagi anak-anaknya. Sedangkan guru hanya tenaga profesional yang membantu orang tua untuk mendidik anak-anak pada jenjang pendidikan sekolah (Zakiyah Darajat).

Guru merupakan orang yang memiliki kualifikasi akademik dan kompetensi sebagai unsur pembelajaran, sehat jasmani dan rohani, serta mampu mewujudkan tujuan pendidikan yang profesional (Mulyasa 2014) (www.maxmanroe.com).

\section{Tugas Guru}

Tugas guru yaitu membimbing peserta anak di didik dalam masa perkembangannya untuk tumbuh seperti orang yang dewasa. Dewasa dalam konteks ini orang yang mempunyai keimanan, keilmuan yang sesuai, dan berakhlak mulia, serta mempunyai keperibadian muslim.

Tugas pokok guru dalam pendidikan ada 3 yaitu:

- Mengajar

Mengajar berarti menyaipaikan ilmu pengetahuan kepada siswa. Menjadikan siswa dari tidak mengerti menjadi mengerti tentang berbagai disiplin ilmu..

- Mendidik

Tugas guru pendidik merupakan tugas yangbisa dikatakan agak sulit. tugas pendidik juga berkaitan dengan sikap dan tingkah laku yang akan dikembangkan oleh peserta didik. Mendidik berarti juga mengubah tingkah laku peserta didik kepada tingkah laku yang baik.

- Melatih

Tugas guru adalah melatih peserta didik untuk memiliki sejumlah keterampilan yang sesuai dengan mata pelajarannya masing-masing. Pada sekolah umum, keterampilan dan kecakapan yang dimaksud adalah keterampilan dan kecakapan dasar. Berbeda dengan sekolah kejuruan lainnya yang memberikan keterampilan dan kecakapan lanjutan.(www.silabus web.id) 


\section{Kriteria Guru Ideal}

- Role Model

Guru ideal merupakan guru yang menjalankan tugasnya secara maksimal sehinnga memberikan hasil sebagaimana diharapkan, dan juga bisa memberikan panutan atau role model yang baik pada peserta didik baik masalah disiplin waktu, mengajar,

- Percaya Diri

Seorang guru yang ideal merupakan guru yang memiliki rasa percaya diri. Guru juga bisa menunjukkan sikap yang positif melalui ekspresi yang tergambar di wajahnya saat mengajar..

- Memiliki Rasa Humor

Seorang guru yang ideal harus memiliki rasa humor yang baik, humorhumor tersebut masih dalam tahap yang wajar dan tidak melampaui batasnnya. Humor akan membawah proses belajar yang menyenangkan..

- Menguasai Materi

Guru ideal itu menguasai materi yang diajarkan. Tentunya seorang guru juga kompeten terhadap materi pembelajaran artinnya menguasai pelajaran yang diajarkan di sekolah.

- .Jelas Dalam Menerangkan

Guru ideal itu menyampaikan materi secara jelas baik dalam tulisan maupun penjelasan di kelas, guru juga akan menghadapi karakter siswa yang bermacam-macam. Seorang guru ideal pasti akan bersikap sabar dalam menghadapi keanekaragam karakter di kelasnya.(www.ahzaa.net)

- Inovatif

Guru ideal itu adalah guru yang inovatif, bisa menciptakan hal-hal yang baru dalam proses belajar-mengajar. Guru mempunyai tugas mentransformasikan ilmu kepada para siswanya. Pembelajaran konvensional bisa dianggap membosankan bagi sebagaian siswa. Dengan pembelajaran yang inovatif, siswa juga akan lebih tertarik untuk belajar dan mencari ilmu.(www.ahzaa.net) 


\section{Cara Menjadi Guru Ideal}

- Kuasai Materi

Poin pertama ini hukumnya wajib. Menguasai materi secara mendalam memang model utama ketika menghadapi murid. Bukan hanya hafal, namun paham. Dengan begitu, sikap atau penyampaian kita di kelas pun akan memancarkan kepercayaan diri, santai, tidak bergantung pada buku sumber (sehingga secara psikologis anak akan yakin akan kedalaman ilmu sang guru).

- Punya Wawasan Luas

Sebagaimana kita mengetahui, informasi dan berita-berita yang datang dengan cepat. Jika kemudian kita sampaikan ke anak-anak.

\section{Asal Muasal Guru}

Guru merupakan pekerja tertua. Lebih dahulu dibandingkan arsitek yang baru ada setelah manusia tidak lagi tinggal di gua. Atau lebih juga dari insiyur metaluargi yang baru pada masa logam dan pengolahannya. Pekerjaan guru ada sejak manusia mampu berfikir dan mengenal ilmu pengetahuan. (www.kompasiana.com)

\section{Arti Seorang Guru}

Menurut saya arti seorang guru adalah orang tua kedua bagi saya, karena guru juga lah yang mendidik, melindungi, kita di sekolah, ada yang bilang guru amerupakan pahlawan tanpa tanda jasa, pendidik yang selalu bisa mengerti perkembangan zaman., selalu menuntas kebodohan.

\section{Kreativitas Guru Sekolah Dasar}

Kreativitas guru Sd bisa di uji dimana saja dan bisa di asah dimana saja. Jadi gk heran kebanyakan guru Sd adalah orang yang kreatif serta teliti, guru sd juga sangat berperan bagi kehidupan anak selanjutnya dimana guru $\mathrm{Sd}$ harus bisa jadi teman dan guru bagi muridnya. 


\section{Referensi}

- Kamis. 27.02.00 https://Maxmanroe.com/vid/umum/pengertian-guru.html

- Kamis. 27.02.00 https://www.silabus.web.id.

- Kamis.27.02.00 www.ahzaa.net/2016/03

- Kamis. 27.02.00 https://www.rosediana.net/2015/03

- Kamis.27.02.00 https://www.kompasiana.com/haryomojo 


\section{"Mewujudkan pendidikan guru sekolah dasar yang ideal"}

1.) pengantar/ pembuka

a. latar belakang pengertian guru (what)

b. tugas guru (why)

2.) karakteristik guru

a. kriteria guru ideal (how much)

b. cara menjadi guru ideal (how)

3.) sejarah guru

a. asal muasal guru (when)

b. arti seorang guru (who)

4.) kreativitas guru sekolah dasar (where)

5.) referensi 